\title{
KARST AND SINKHOLES AT NASH DRAW, SOUTHEASTERN NEW MEXICO (USA)
}

\author{
Andrea K. Goodbar \\ Geospatial Collaborative \\ 3027 E. Derrick Road, Carlsbad, NM 88220, USA, agoodbar.newmexico@gmail.com \\ Dennis W. Powers \\ Consulting Geologist \\ 170 Hemley Road, Anthony, TX, 79821, USA,dwpowers@evaporites.com
}

James R. Goodbar

Goodbar Consulting

3027 E. Derrick Road, Carlsbad, NM, 88220,USA, goodbarjr@gmail.com

Robert M. Holt

Department of Geology and Geological Engineering

University of Mississippi, University, MS, 38677,USA,rmholt@olemiss.edu

\begin{abstract}
Nash Draw is an enclosed basin located in southeastern New Mexico (USA). Nash Draw developed through solution and erosion of upper Permian rocks of the Rustler and Salado Formations. Surface features of sinkholes, swallets (including alluvial dolines), caves, and karst valleys occur principally in and on outcrops to subcrops of gypsum of the Rustler. The underlying Salado is relatively shallow, and groundwater is removing halite from the upper part, leaving a residue of insolubles and a brine-saturated zone. Potash refining over nearly 90 years affects the surface hydrology and shallow groundwater of Nash Draw.
\end{abstract}

Nash Draw has no external surficial drainage. Thirty internally drained basins have been identified from topography ( $\sim 3-\mathrm{m}$ to 6-m divides) and field checking. For each 100-m square within a basin, factors such as active or vegetated channels, presence of surficial karst features, and curve number (a runoff parameter) have been assigned using field investigations, soil maps, and aerial photography. For comparison, GIS analysis included air photo interpretation, DEM analysis, remote sensing and GPS field mapping of karst features. GIS analysis identifies a relationship between the drainage basins, surface flow models and feature points. This relationship terminates surface flow models at sink locations and flow models remain within the identified drainage divides. Ground truthing of historical air photo interpretation and DEM analysis indicate that sinkhole occurrence and character have changed over time.

Nash Draw karst features continue to be cataloged, using field work and aerial photography. To differentiate and catalog Nash Draw karst features, four types are identified. More than three-fourths of the Nash Draw surface has been surveyed in some detail.

\section{Introduction}

Nash Draw is a topographically enclosed basin located in southeastern New Mexico (Figure 1). Nash Draw has been referred to as a "dog-bone shaped depression" (Lambert, 1978). Our focus is this topographic feature. It is adjacent to, but topographically separated from, the Pecos River. [The term "Nash Draw" is also applied specifically to an ephemeral, discontinuous water course in a small segment of the larger "Nash Draw."] The boundaries of Nash Draw are sometimes drawn differently as there is an inner escarpment (more commonly used as a boundary) and an outer partial escarpment. The Nash Draw watershed is a much larger feature defined by the entire area that would theoretically drain toward the topographic low with sufficient precipitation and runoff. Extensive sand dune cover east of Nash Draw and limited rainfall means that a large area of the watershed contributes no known runoff to Nash Draw. The southern portion of Nash Draw has several salt playas; Laguna 


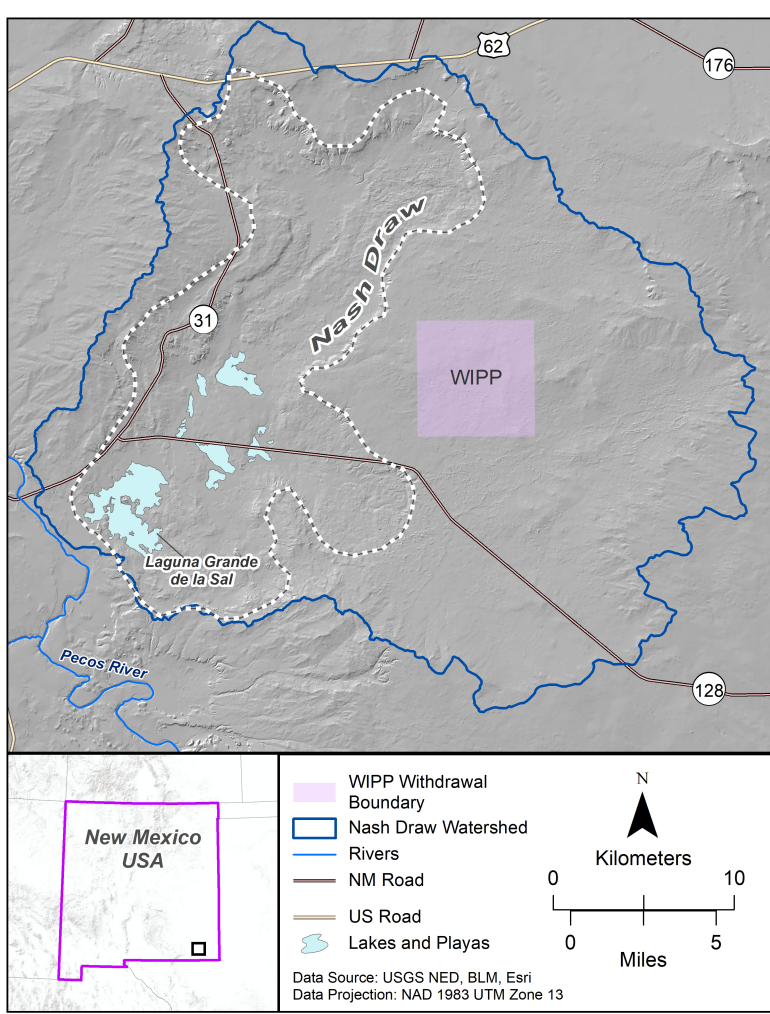

Figure 1. "Dog-bone" shaped Nash Draw depression (white/black dashed outline) within larger potential watershed area (blve outline). Watershed designation: Salt Lake. HU: 1306001117 . For reference, the approximate center of the WIPP site is longitude -103.7914 degrees, latitude 32.3697 degrees.

Grande de la Sal is largest and is the lowest part of Nash Draw.

Upper Permian evaporite-bearing formations (Figure 2) that underlie Nash Draw are the Castile, Salado, and Rustler Formations. The upper Salado halite beds have been dissolved under Nash Draw, with amalgamated gypsum and siliciclastics as the residue. The Rustler variably crops out in the lower parts of Nash Draw, and the sulfate beds are the principal point of attack and development of karst features. The redbed Permotriassic(?) Dewey Lake Formation (aka Quartermaster Formation) and Triassic Dockum Group (aka Chinle Group) crop out around the periphery. There is a thin, variable veneer of mainly Pleistocene fluvial sediments and pedogenic calcrete, gypsites, and dune sand within Nash Draw. Underlying formations dip $\sim 1$ degree to the east, and erosion in the Pecos River valley eventually exposed the evaporites

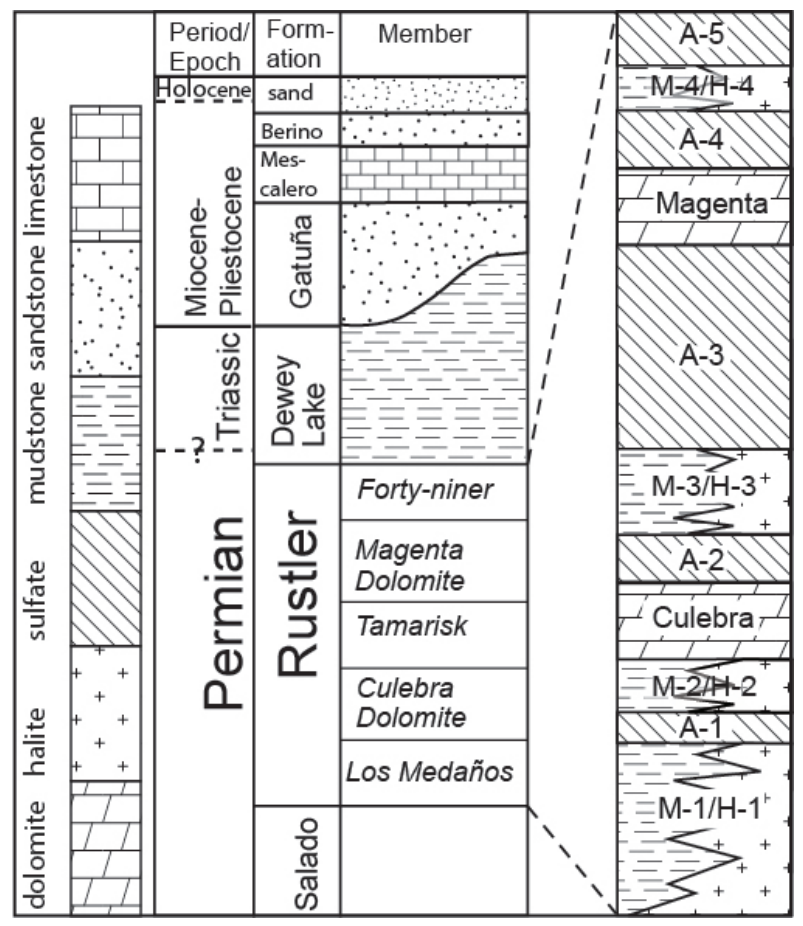

Figure 2. Principal stratigraphic units at Nash Draw. M-x/H-x portions of the Rustler indicate mudstone $(M-X)$ to halite $(H-x)$ facies changes from left (west) to right (east) in southeastern New Mexico. Modified from Powers et al. (2003).

to meteoric water at the surface. Dissolution and erosion created Nash Draw.

Nash Draw was brought to the attention of geologists by Willis T. Lee (Lee, 1925). He explored some of northcentral Nash Draw, reporting on karst features and proposing a process of "erosion by solution and fill" to explain the development of the draw. Robinson and Lang (1938) surveyed the geology and hydrology of Nash Draw in support of the growing potash industry in the area. They discovered and reported the presence of brine underlying the main axis of Nash Draw and proposed that solution of upper Salado halite created the draw and the brine. They also found that this brine was upwelling locally in the nearby Pecos River. Vine (1963) reported on the geology of Nash Draw and prepared a 15-minute quadrangle geological map.

After the beginnings of the Waste Isolation Pilot Plant (WIPP) project in the area in 1974, further studies of Nash Draw summarized the hydrology (Mercer, 1983) 
and geology (Bachman, 1980, 1981, 1985; Lambert, 1983). More detailed studies have emerged since that are variably related to Nash Draw geology and hydrology. As an example, evidence for dissolution is more precise now, generally ruling out significant deposition of Rustler halite beds in the area of Nash Draw (Holt and Powers, 1988, 2010; Powers and Holt, 2000); the locus of dissolution of Rustler beds in Nash Draw is primarily sulfate beds.

In this article, we summarize the current status of our studies of Nash Draw. Although some work referred to here has been directly or indirectly funded by WIPP or other entities, the work continues mainly by personal efforts because of our interest in the complexities of the development of Nash Draw through solution, erosion, and fill.

\section{Basins Within Basins}

Using topographic maps, aerial photography, and ground checks, Powers (2014) divided the area of Nash Draw and some adjacent areas that could contribute runoff into 30 discrete basins (Figure 3 ). The main criterion was that about 3-6 m ( 10-20 ft) of topographic relief was needed to divide basins. Some obvious areas of sand dunes with no evidence of drainage were attached to basins by dividing along a general topographic high. Most of the area east of Nash Draw in the greater watershed was neither divided into basins nor assigned other hydrologic parameters because there is no evidence from drainages or other features that they currently contribute to runoff into Nash Draw. Other data included general mapping of active and inactive drainages, areas with individual karst features or collections of features, runoff curve values (US Department of Agriculture, 1986), and an estimate of areas where the water-bearing Culebra Dolomite Member of the Rustler is confined. Because of modeling constraints for WIPP hydrology at the time, these parameters were assigned to $100 \mathrm{~m}$ x $100 \mathrm{~m}$ blocks or cells. Basin boundaries and features are associated with a block, not located precisely.

The initial objective for dividing Nash Draw into basins and assigning other parameters was to provide data for modeling potential recharge to the Rustler, specifically to the Culebra. Although no such modeling has apparently been undertaken, the basins provide a framework for relating drainages and points (e.g., karst features) for

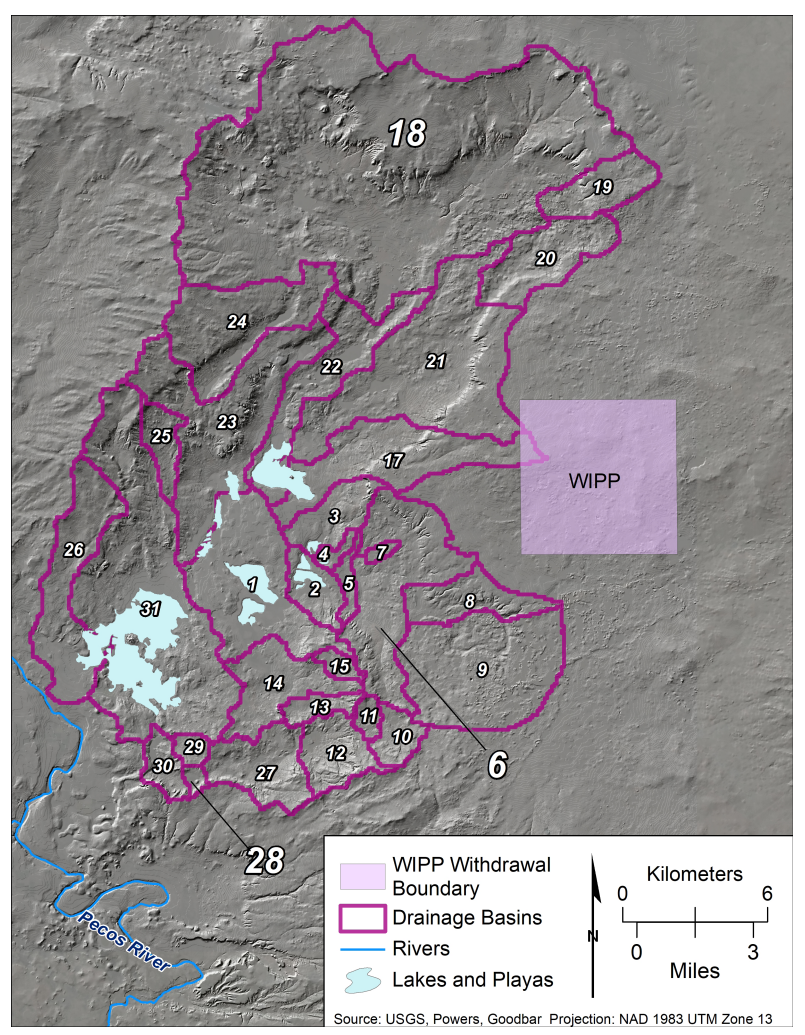

Figure 3. Thirty topographic basins were delineated by Powers (2014). Basin 16 does not exist; it was combined with basin 14 after re-evaluating the divide between them. Nash Draw underlay from USGS NED.

potential recharge to the underlying Rustler as well as some more recent sediments in Nash Draw. The basin framework can be compared and contrasted to GISbased evaluations of topography and surface hydrology, for example, as discussed later. Contrasts also can be evaluated in the field, resulting in refined basin identification and characterization.

The largest basin (\#18) is at the north end of Nash Draw. It is $\sim 140 \mathrm{sq} \mathrm{km} \mathrm{(} \sim 54 \mathrm{sq} \mathrm{mi})$. Two main characteristics are clear: basin 18 includes most of the active natural surface drainages within Nash Draw, and there are no exposed Rustler evaporites except near the sump at the southern end of the basin. At the southern end, surface waters recharge in karst features developed in upper Rustler beds. Most of basin 18 displays no identified surface karst features.

The south-central part of Nash Draw is dominated by basins that are now collecting runoff after precipitation, 
brine water from potash mining tailings, and some discharge from springs. Rustler sulfate beds and dolomite are at and near the surface in these areas, and various karst features are more common. Topographic separations between basins are commonly more subtle.

The smallest basin (\#28) is at the south end of Nash Draw. It is $\sim 0.96 \mathrm{sq} \mathrm{km}(\sim 0.37 \mathrm{sq} \mathrm{mi})$ in area, with a shallow closed depression and more or less centripetal drainage. The south side is an escarpment with a divide between Nash Draw and a different watershed. No points of recharge such as sinkholes have been found. Soluble evaporites are estimated to be more than $50 \mathrm{~m}$ below surface. The sediments around the south side of basin 28 are mainly late Cenozoic (Gatuña Formation) while the fill is at least partly Holocene. Nearby drillhole logs reveal a considerable thickness of upper Salado has been removed. The generally accepted explanation is that these soluble rocks have been dissolved, although much of the overlying Rustler geophysical log signature remains intact. Some of these relationships are being investigated regionally, and that may resolve some ambiguities in the local Nash Draw setting.

An unexpected result of defining the basins was to find some local basin lows are connected to very large areas of drainage. Basin 6, in the southeastern arm of Nash Draw, has an area of slightly more than $23 \mathrm{sq} \mathrm{km} \mathrm{(} \sim 9 \mathrm{sq}$ mi) (Figure 3). On both south and north ends, it includes topographically higher areas. Several square kilometers near the lowest point display interconnected drainage on relatively hard ground. The lowest point is a karst valley with numerous sinks, dolines, and caves, and it is believed to have been flooded during major rainfall in September 2004 (Powers et al., 2006; Hillesheim et al., 2006).

This same area was directly observed to have flooded to the point of overflow to the next basin to the west after a major rainfall in September 2014 (Figure 4a,b). Although much of the water had infiltrated in the valley floor within a week or so, some caves and sinks remained filled with stagnant water for several weeks. However much the subsurface system may be interconnected, it does not allow straightforward passage of water. A perennial spring in an adjacent basin indicates considerable storage in an area that receives an average annual rainfall of $\sim 33 \mathrm{~cm}$ ( $\sim 13$ inches) (Powers et al., 2006). Prior field observations of these same features indicated more rapid
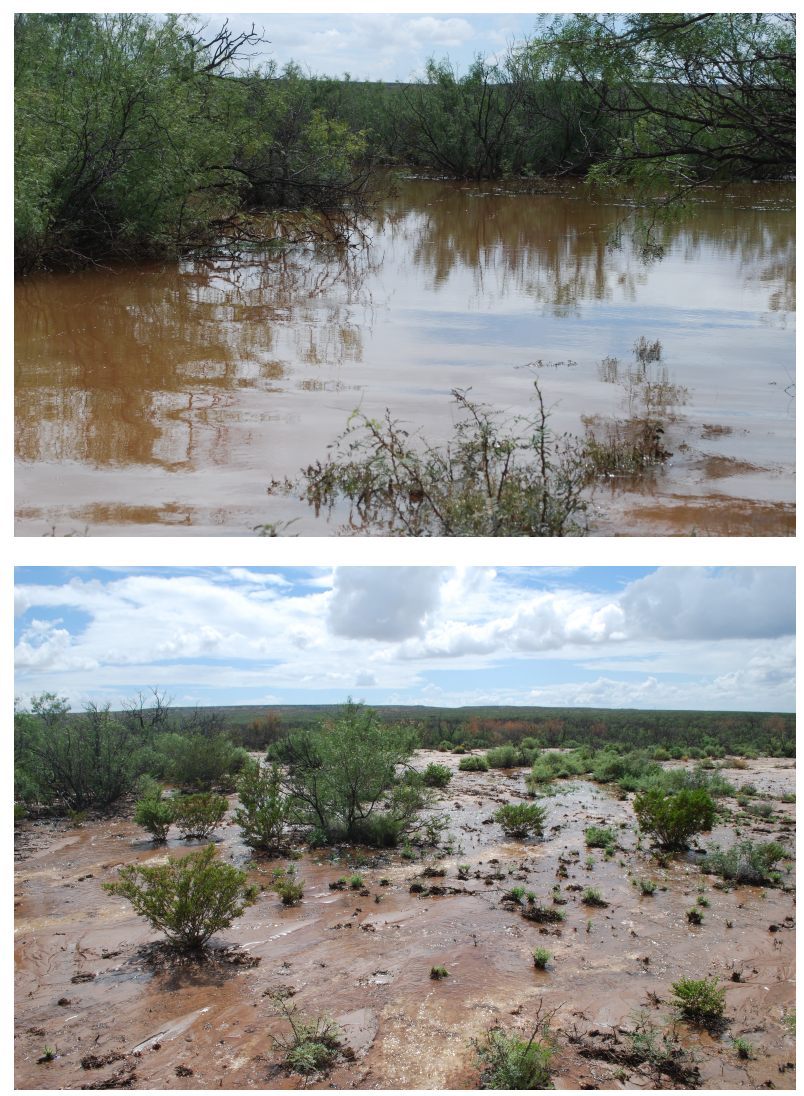

Figure 4. A. Flooded low area of basin 6 on 9/20/20 14; B. Overflow from basin 6 west to ba$\sin 5$ on $9 / 20 / 2014$.

water intake; the system may not present a consistent storage or permeability over time.

At this stage, basin delineation is helpful for understanding points and areas for recharge to the underlying sediments and rocks. It helps organize features into potentially useful groups. Nevertheless, we recognize that the subsurface hydrology (as discussed below) in Nash Draw is complicated and is unlikely to be organized the same way as the surface basins.

\section{Geographic Information System (GIS)}

\section{Approach and Data}

Four elements are included to date in the GIS analysis of Nash Draw: DEM (digital elevation model) analysis of basins and features, field mapping using the global positioning system (GPS) to locate specific features, interpretation of old and new aerial photos, and remote sens- 
ing. Many details of the software, hardware, and tools applied here are described in Goodbar (2019).

\section{Digital Elevation Models (DEM) Analysis}

United States Geological Survey (USGS) National Elevation Data Set 1/3 Arc Digital Elevation Models (DEM) were used for surface flow analysis. The resolution is approximately $10 \mathrm{~m}$, and the data conform to North American Datum of 1983 (NAD83). The ESRI ArcMap Spatial Analyst Hydrology Toolset was used to create raster data of flow accumulation, flow direction, and link surface flows paths. The final vector output is a stream/surface flow feature set which identified surface flow paths within Nash Draw. The Hydrology Toolset was used to identify sinks within the DEM as well as locate and address error within the DEM.

To evaluate surface flow, threshold values can be set for water fill in sinks or lows to cause flow out of the sink or low. Threshold values of $3 \mathrm{~m}$ and $9 \mathrm{~m}$ were used to generate these flow paths. In addition, drainage basins were generated using the same parameters.

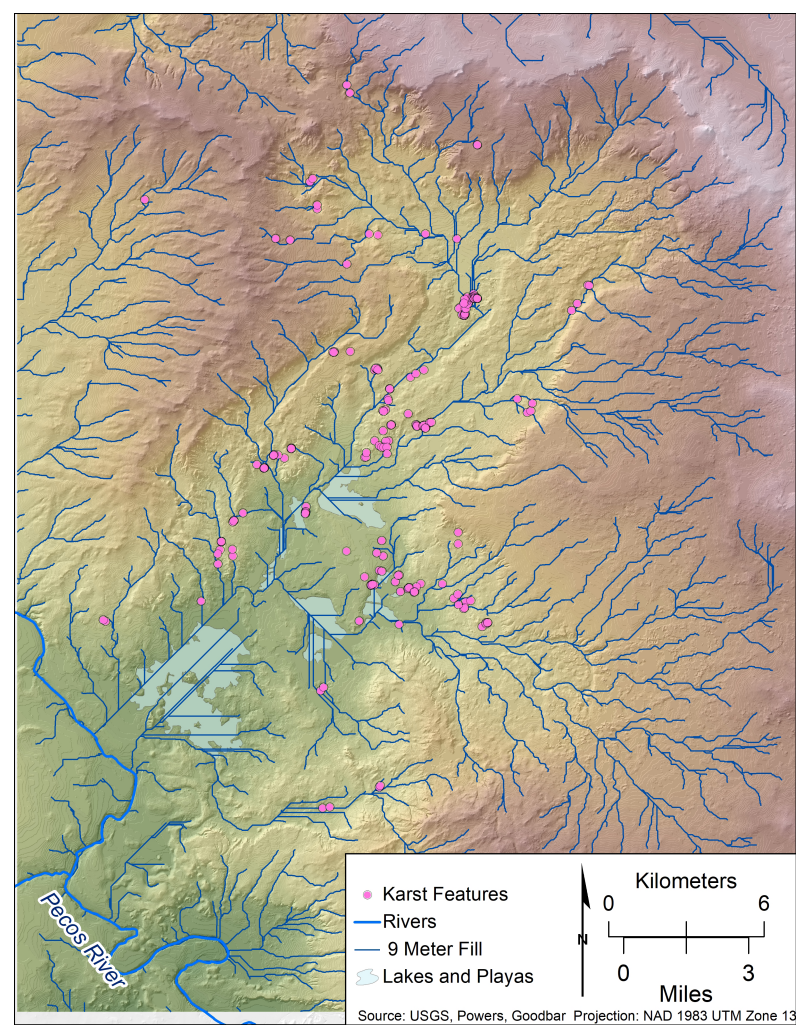

The threshold value of $9 \mathrm{~m}$ generated flow paths (Figure 5a) that ignore many sink areas observed in the field to capture surface flow. A threshold value of $3 \mathrm{~m}$ generated flow paths (Figure $5 b$ ) that are much more similar to field observations, with capture of surface flow more commonly terminating at or near alluvial dolines, swallets, or caves. When no threshold value is assigned, which is equivalent to not filling sinks, the surface flow terminates at natural sinks, but depressions such as interdune area or errors in elevation also terminate flow. Drainage patterns from the 9-m threshold (Figure 5a) are approximately what one would expect from this area with sufficient rainfall to develop integrated surface drainage. Most of the topographic basins are combined, and the model basin (Figure 6a) corresponding to the 9-m threshold is similar to the Nash Draw watershed derived by topographic map analysis (Figure 1). The flow system and basin derived from the 3-m threshold correspond somewhat better to basins outlined based on topography and field inspection (Figure 6b).

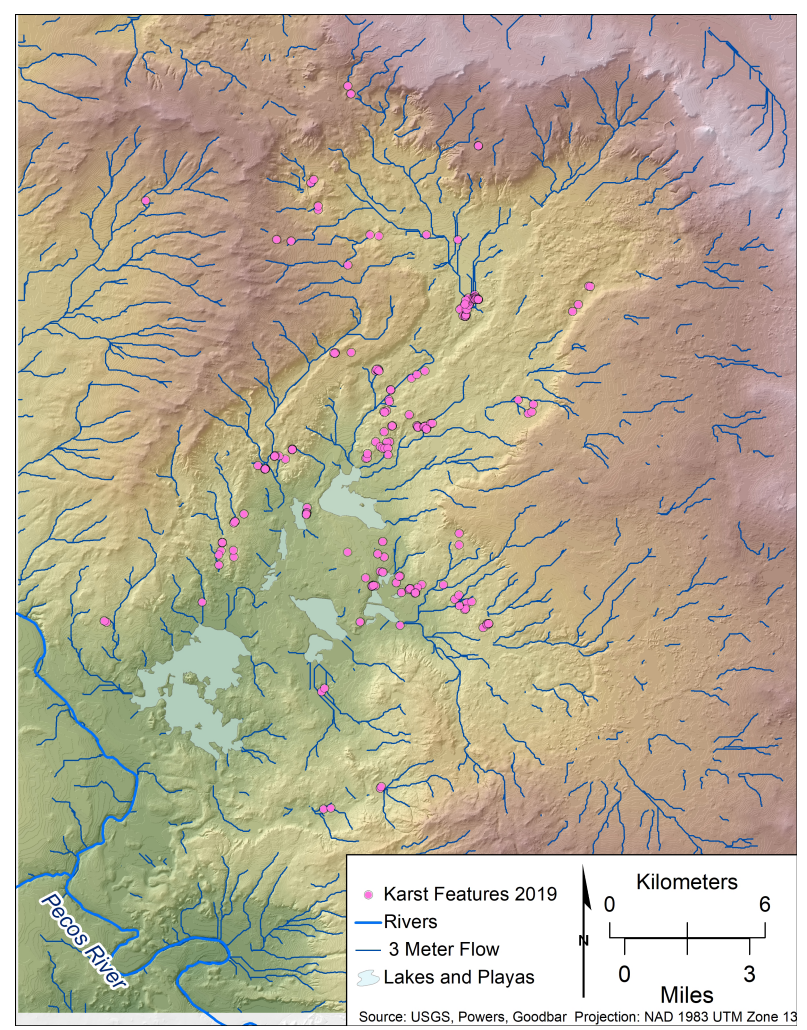

Figure 5. A. Surface drainage analysis (ArcBasin) with 9-m threshold for flow integrates all drainage, similar to the watershed area. Drainage is connected to the Pecos River; B. Surface drainage analysis (ArcBasin) with 3-m threshold for flow develops many low sinks. 

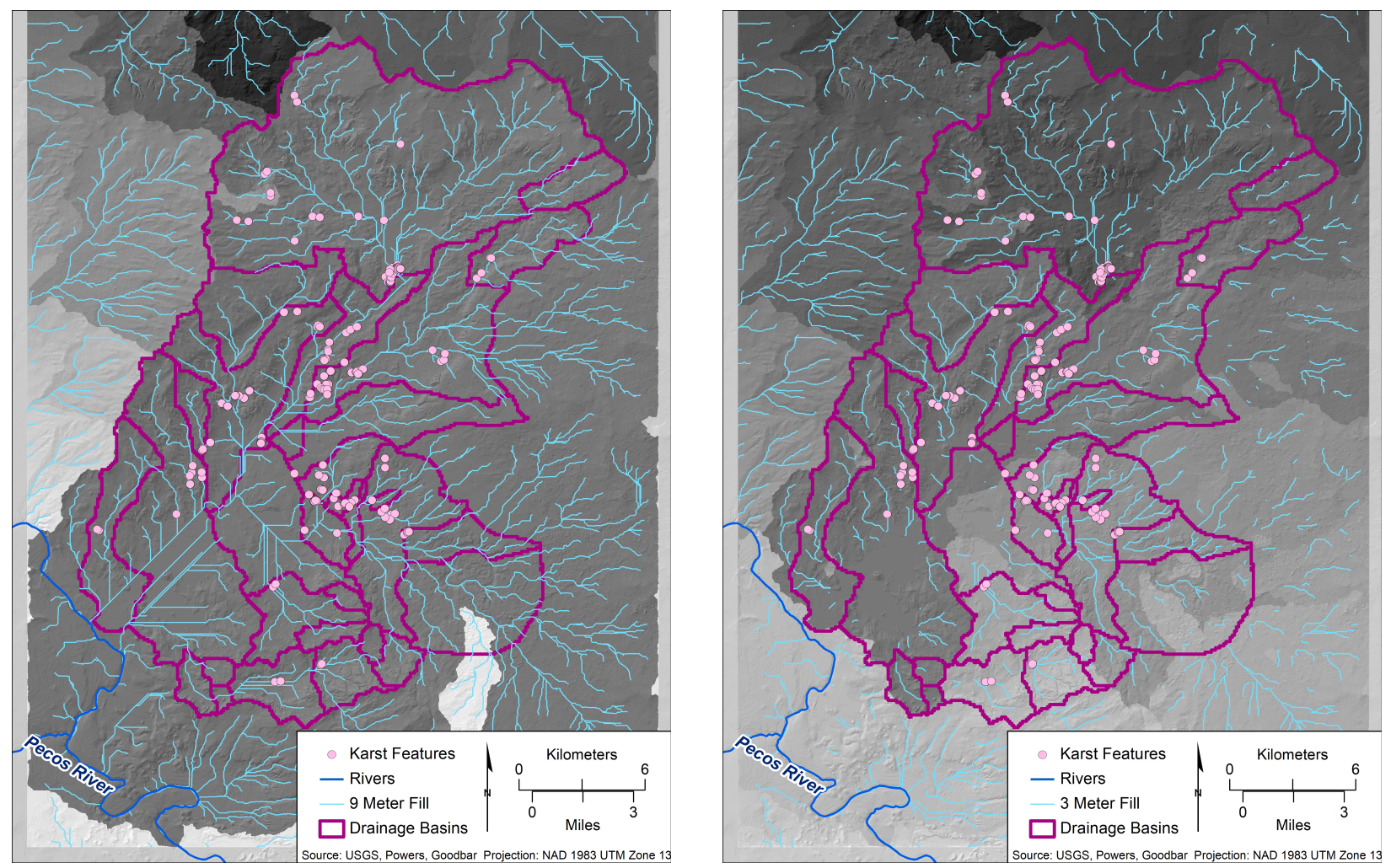

Figure 6. A. Surface drainage analysis with 9-m threshold for flow compared to basins differentiated with topographic map and field survey (Powers, 2014). Karst features are included where they have been observed and located (see Field Mapping with Global Navigation Satellite System); B. Surface drainage analysis with 3-m threshold for flow compared to basins differentiated with topographic map and field survey (Powers, 2014). Karst features are included where they have been observed and located (see Field Mapping with Global Navigation Satellite System).

Basin boundaries are commonly transgressed by drainage. This is reasonable, as the topographic threshold was $10-20 \mathrm{ft}(\sim 3-6 \mathrm{~m})$. The 9-m threshold generally will integrate many basins delineated by the topographic analysis. The 3-m basin subdivisions correspond better to the topographic basins. Basin 18 becomes divided into two larger subbasins and several smaller subbasins with a 3-m threshold (Figure 7). The 10-m resolution for the DEM is not sufficient to delineate through-going water courses in various areas, whether the 3-m or 9-m flow systems are considered.

Nevertheless, these DEM models of flow paths and basins are useful as they may pick up subtle relationships between separated drainages, and they can point out that topographically delineated basins may be more related than is initially apparent. Major precipitation events or differences in earlier climate may have united them more closely.

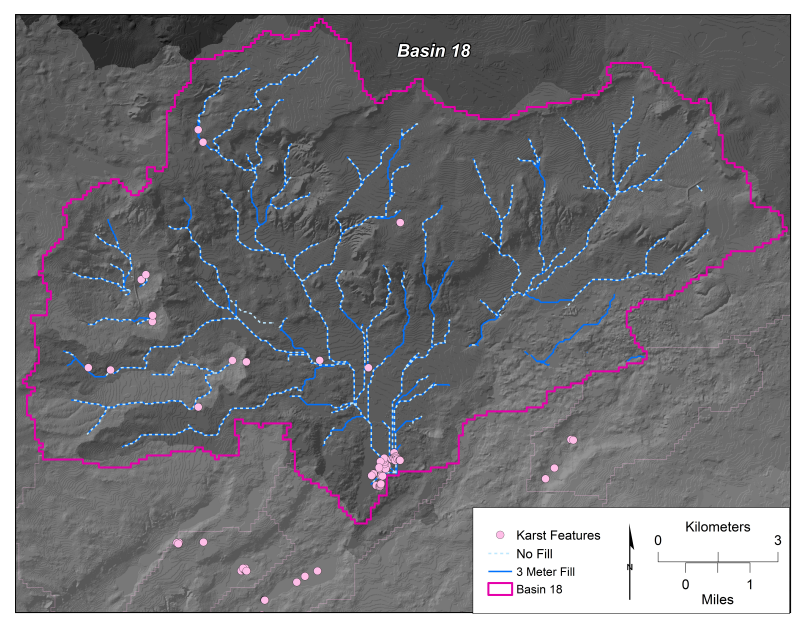

Figure 7. Detail of surface drainage analysis with 3-m threshold for basin 18. Karst features are included where they have been observed and located (see Field Mapping with Global Navigation Satellite System). 


\section{Field Mapping with Global Navigation Satellite System}

Until recently, there has been little systematic mapping of karst features in Nash Draw. Bachman (1981) remapped the geology of Nash Draw on four 7.5-minute quadrangle maps and noted several larger examples. Powers and Owsley (2003) reported karst features as they were related to the realignment of NM128, but they did not report exact locations. Powers et al. (2006) also reported on karst features but did not provide exact locations. Powers (2014) catalogued evidence of possible recharge points, including specific karst features, broad karst areas, low vegetated collection points, and brine lakes. These, however, were again only reported as present within the $100 \mathrm{~m} \times 100 \mathrm{~m}$ blocks, thus lacking detailed location data.

For several years, specific features have been mapped (mainly by the Goodbars) in the field using systems capable of 1-2 m horizontal accuracy. As the work developed, the features have been defined as sink, swallet, cave, karst feature (includes remnant karst, pits, springs, etc), or other (miscellaneous info, including survey markers, etc.). Elevations are recorded or obtained from DEM. Field investigations are directed by word of mouth, reported features in the topographic analysis, aerial photo analysis, DEM sink analysis, and old-fashioned field treks. This project continues.

\section{Aerial Photo Interpretation}

Aerial photos from 1945, documenting the area of potash mining and resources across Nash Draw, have been compared with later photography. National Aerial Photography Program (NAPP) imagery for 1996 and more recent National Agriculture Imagery Program (NAIP) photographs are available in various formats. Google Earth contributes imagery in an accessible form for identifying and comparing features. Several recent Google Earth iterations are of excellent quality.

Aerial photos of a small area near a potash mine tailings pile on the western margin of Nash Draw illustrate local contrasts in features through time (Figure 8). The 1945 photograph does not appear to show the sinks easily found in 2016 NAIP imagery. Color aerial photos from October 1976 (taken for WIPP) reveal three of the sinks and the nearby tailings pile. NAPP images from 1996 are similar. More recent photos show that the additional sinks in the 2016 photographs have been very clear since at least 2007. Current Google Earth images (lat 32.4179 degrees, long -103.9195 degrees) are even clearer.

The collection or sump area for surface flow within basin 18 also has evolved (Figure 9). In 1945, drainage (indicated by R) appears to be in the south-central area of the sump. There are modest depressions south of this recharge point, and the current drainage/recharge point is not evident. By 1996, the main recharge point is in the

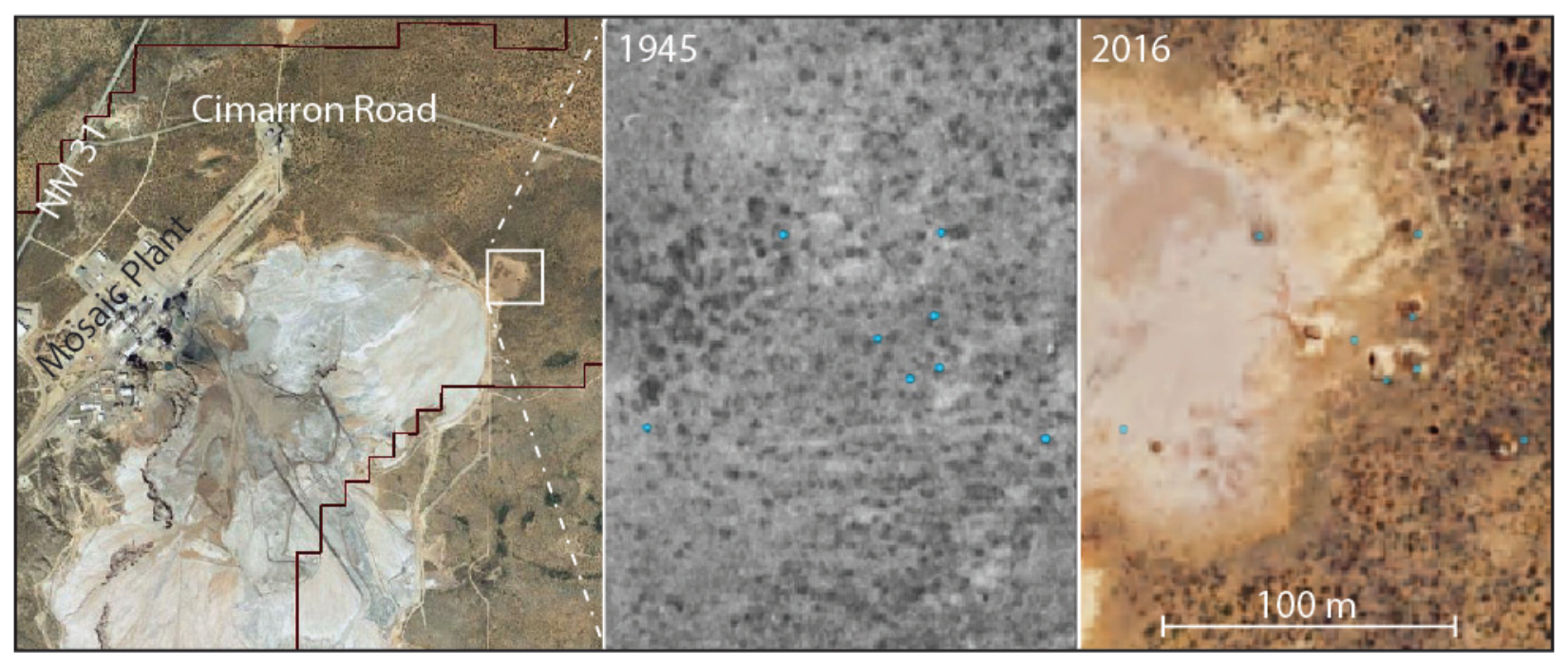

Figure 8. Well-developed small sinks in the vicinity of a potash tailings pile on the western side of Nash Draw are not apparent in 1945 aerial photography (photoreferenced for location). Best resolution available. 


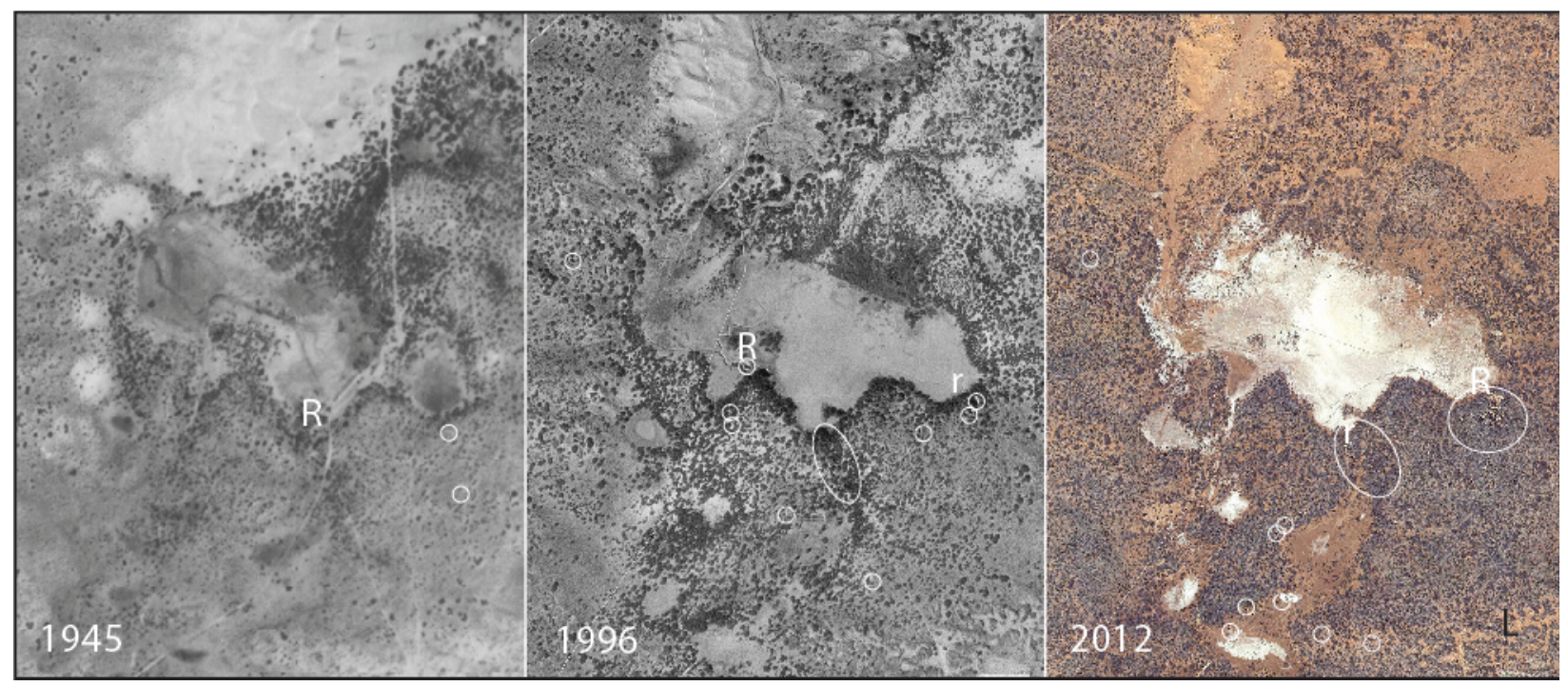

Figure 9. The sump at the southern end of basin 18 illustrates changes with time in Nash Draw. Principal sink/recharge points (R) have changed with sediment influx. Drainage developing in 1996 at east end marked by "r." A number of small sinks (white circles) have also developed with time.

southwest, and the current recharge point at the eastern end of the sump shows visible collapse. The sump area also had expanded by 1996. The November 2012 image shows that the 1996 recharge point was no longer active, and the east recharge point dominated. The east recharge point is still dominant. Field study shows that the sinks in the eastern end developed in the Magenta Dolomite Member of the Rustler and the overlying Forty-niner Member basal sulfate bed. Both field investigations and study of photos confirm that some of the sinks in basin 18 south of this sump developed by 1996 and are persistent. Some floods in the last few years have transported red sediment that has at least partially plugged some individual features (Figure 10). Scallop marks in gypsum (Figure 11) of the Forty-niner at the cave entrance of the swallet in Figure 10 measure $6+\mathrm{cm}$ across and indicate a steady flow of water for an extended period.

\section{Remote Sensing}

Landsat imagery has not proven useful in extracting specific location information on sinkholes because the resolution isn't sufficient.

InSAR data have been used recently to interpret surface subsidence related to potash mining (Rucker et al., 2013; Zhang et al., 2018). InSAR and related techniques are not known to have been applied yet to Nash Draw to detect the effects of dissolution/karst.

\section{Hydrology}

While investigating water sources to support the early potash industry in the area, Robinson and Lang (1938) reported that a brine-saturated zone ("brine aquifer") underlies much of Nash Draw. The brine was located stratigraphically mainly in the solution residue of the upper Salado and in the basal Rustler. Robinson and Lang concentrated much of their study at or near Laguna Grande de la Sal in the southern end of Nash Draw (Figure 1). [Laguna Grande de la Sal is the lowest area in Nash Draw. Both potash tailings water and natural spring(s) discharge into the lake, where industrial salt is produced]. Details of the work by Robinson and Lang (1938) indicate that 1 ) the salinity of water encountered in the zone was quite variable, 2) that it was unlikely brine from Laguna Grande was infiltrating to the brine aquifer in view of much fresher water encountered below Laguna Grande, 3) that brine flow was from north to south-southwest, and 4) that brine from the brine aquifer was being discharged into the Pecos.

WIPP drilled additional wells in Nash Draw during the late 1970s to monitor water levels and chemistry of Rustler units and the contact zone with the Salado. Mercer (1983) summarized findings from these wells, generally confirming the flow direction proposed by Robinson and Lang (1938). In the early 2000s, WIPP drilled six additional wells within or adjacent to Nash Draw, focusing on the Culebra as a water-bearing unit. These are still be- 


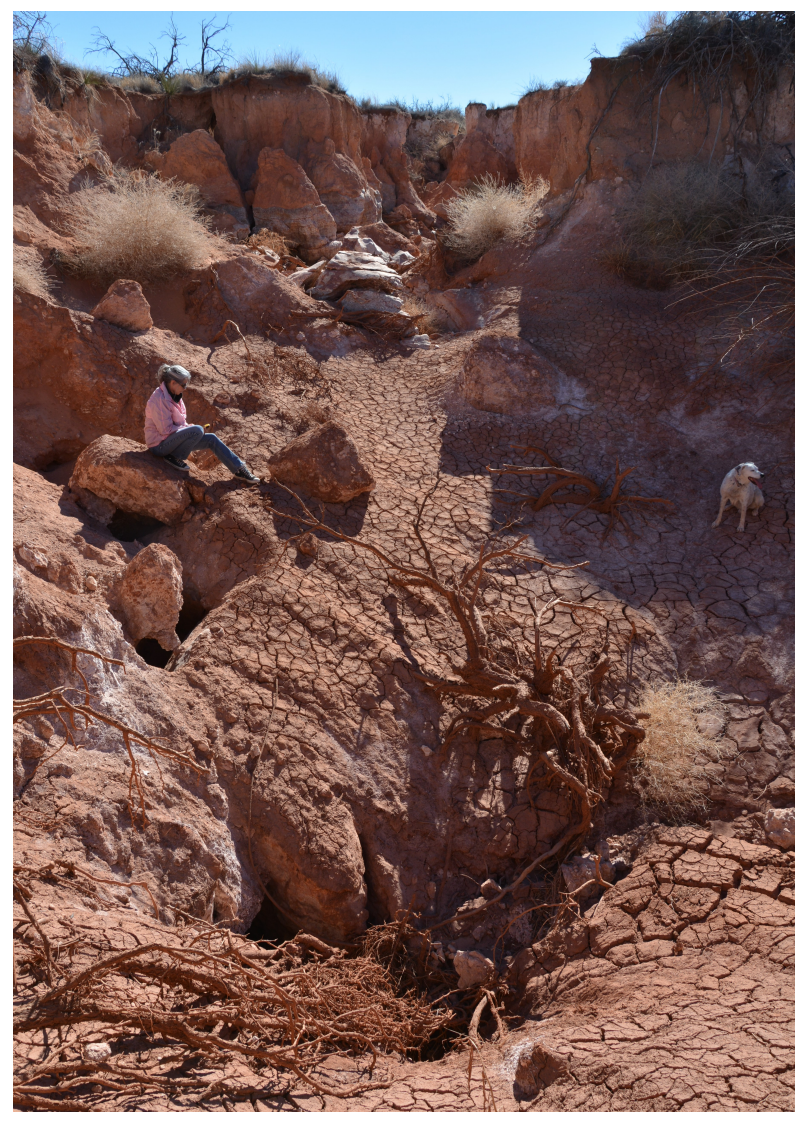

Figure 10. The primary swallet and associated cave in basin 18 in January 2014 captured most of the water entering the basin. At the base of the sinkhole, a bedrock crevasse dropped $\sim 5 \mathrm{~m}$ to a horizontal passage trending south for $\sim 8 \mathrm{~m}$ before constrictions halted exploration.

ing monitored, while some of the earlier wells have been plugged and abandoned.

There are three locations around the margins of Nash Draw where potash tailings water is being added to the surface. It is clear to even the casual observer that the surface and near-surface hydrology is being affected by the influx of potash mine tailings brine. Goodbar and Goodbar (2014) reviewed some of these effects, following earlier assessments by Geohydrology Associates $(1978,1979)$. Powers et al. (2006) described some of the karst features and related hydrology. Major precipitation events, such as in September 2014, can create pressure pulses in the Culebra where it is closely monitored by WIPP. Such pressure pulses can clearly be related to infiltration and changes in groundwater storage in Nash

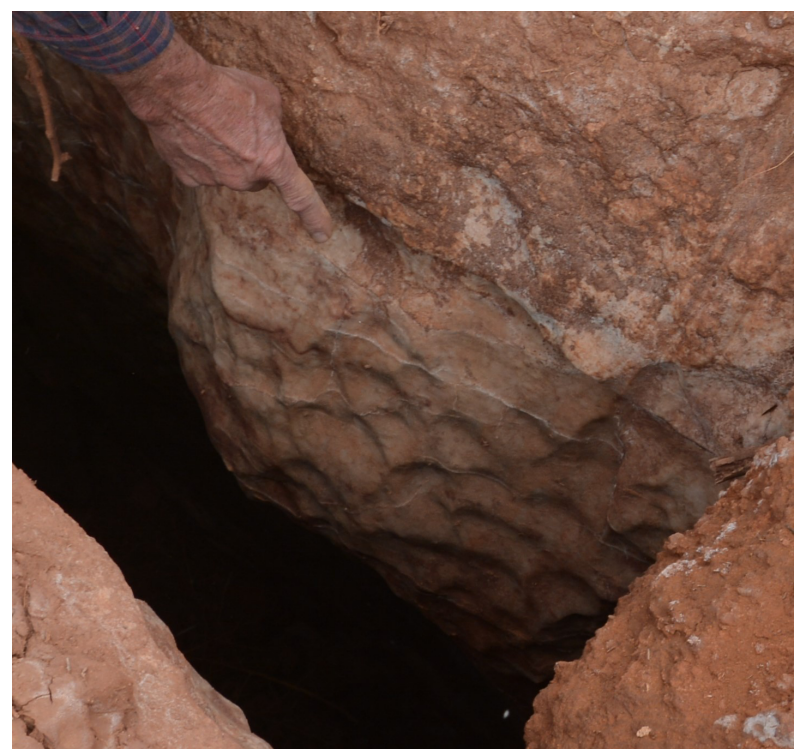

Figure 11. Scallops at the cave entrance of the primary swallet for basin 18 are $6+\mathrm{cm}$ wide and indicate steady and lengthy inflow.

Draw (e.g., Hillesheim et al., 2006), although it is still not possible to isolate the locus of infiltration (if there is one). It also needs to be pointed out that there are no available data indicating whether similar pressure pulses also occur in the brine aquifer; such data would help to determine the degree of confinement of the brine aquifer.

Goodbar and Goodbar (2014) outline experimental parameters for tracer tests to help evaluate the hydrology of the karst system in Nash Draw. No full-scale tracer experiment is presently being undertaken. However, the implementation of the first phase of a groundwater trace, from Laguna Grande to the Pecos River (Goodbar and Goodbar, 2017), is now concluding.

\section{Dissolution}

Upper Salado dissolution has been evaluated extensively through geophysical logs, mapping of shafts at WIPP, and drillhole cores. Along the eastern margin of Nash Draw (Livingston Ridge), concentrated well data show a narrow margin over which the upper Salado is removed (Powers et al., 2003, 2006; Holt and Powers, 2010). Elevation on the Culebra shows a structural trough along the front of the escarpment of Livingston Ridge. Livingston Ridge overlies the high adjacent to the structural trough. The top of Salado salt is interpretable in these wells and is lower in elevation under the structural trough. Holt 
and Powers (2010) propose that salt is dissolved along the margin by infiltrating low-salinity water along the escarpment. The data are somewhat limited to map top of Salado salt throughout Nash Draw, but that surface is clearly variable in elevation/depth within Nash Draw.

Most of the sinks, swallets, and caves are developed in Rustler gypsum beds. Field inspections indicate that a significant proportion are developed by preferential solution of gypsum beds at the top and base of the Magenta. The Culebra is at or very near the surface in a large area east of Laguna Grande. There are few sinks or caves in this area. There are larger depressions, likely due to deeper dissolution of upper Salado halite (Powers et al., 2006).

\section{Summary}

Nash Draw is a large karst valley developed by solution of upper Salado halite. Many of the surficial features (caves, sinks, swallets) are developed in sulfate beds of the overlying Rustler. A natural brine-saturated zone in the Salado dissolution residue and basal Rustler underlies a significant part of Nash Draw and flows to the south-southwest, eventually discharging into the Pecos River. The brine zone appears to be separated from vertical recharge in the vicinity of Laguna Grande, as there are fresher water zones between the brine lake and the saturated brine zone. Major precipitation events do cause pressure responses in the Culebra where it is confined adjacent to the draw. It is possible there is some potential recharge of the Culebra in Nash Draw. Nevertheless, the shallow and surface hydrology of Nash Draw is greatly disturbed by discharge of tailings water from potash mines.

Our focus is to continue to develop a detailed data base of the Nash Draw karst features, develop a better understanding of the evolution of karst features, and refine ideas of surface and near-surface hydrology. Tracer tests have potential to resolve some of the flow paths and rates, but the tests would have to be carefully designed and executed, and such tests would require a long-term perspective and commitment to maintain.

On the horizon: publish a detailed data base of Nash Draw karst features, develop and report a more detailed history of the development of Nash Draw, and acquire partners to continue the work.

\section{Acknowledgements}

Some of the background work incorporated in this article has been funded by various organizations. Nevertheless, the analysis does not represent the views of any organization or government agency.

We also appreciate two helpful, detailed reviews of the draft manuscript.

\section{References}

Bachman GO. 1980. Regional geology and Cenozoic history of Pecos region, southeastern New Mexico. US Geological Survey Open-File Report 80-1099. 116 p.

Bachman GO. 1981. Geology of Nash Draw, Eddy County, NM. US Geological Survey Open-File Report 81-31. 10 p.

Bachman GO. 1985. Assessment of near-surface dissolution at and near the Waste Isolation Pilot Plant (WIPP), southeastern New Mexico. Albuquerque (NM): Sandia National Laboratories SAND84-7178. 33 p.

Geohydrology Associates. 1978. Groundwater study related to proposed expansion of potash mining near Carlsbad, New Mexico. Bureau of Land Management contract YA-512-CT7-217.

Geohydrology Associates. 1979. Water resources study of the Carlsbad potash area, New Mexico. Bureau of Land Management contract YA-512-CT8-195. $86 \mathrm{p}$.

Goodbar AK. 2019. Summary of GIS analysis and GPS field mapping in Nash Draw, Eddy County, New Mexico migrating a regional study to open source. 32 p. https://www.researchgate.net/profile/ Andrea_Goodbar.

Goodbar J, Goodbar A. 2014. A method to investigate karst groundwater flow in Nash Draw, Eddy County, New Mexico, to delineate potential impacts of potash industry discharge and runoff. In: Kuniansky EL, Spangler LE, editors. US Geological Survey karst interest group proceedings, Carlsbad, New Mexico, April 29 May 2, 2014. US Geological Survey Scientific Investigations Report 2014-5035. p. 98-107. 
Goodbar J, Goodbar A. 2017. Nash Draw groundwater trace: Phase one implementation. In: Niemiller ML, Slay ME, Bitting CJ, editors. Proceedings of the 22nd National Cave and Karst Management Symposium. p. 88-92. http://nckms.org/ wp-content/uploads/2018/05/2017_NCKMS_ Proceedings.pdf

Hillesheim MB, Beauheim RL, and Richardson RG. 2006. Overview of the WIPP groundwater monitoring program with inferences about karst in the WIPP vicinity. In: Land L, Lueth VW, Raatz W, Boston P, Love DL, editors. Caves and karst of southeastern New Mexico. New Mexico Geological Society Fifty-seventh Annual Field Conference Guidebook. p. 277-286.

Holt RM, Powers DW. 1988. Facies variability and postdepositional alteration within the Rustler Formation in the vicinity of the Waste Isolation Pilot Plant, southeastern New Mexico. Carlsbad (NM): US Department of Energy WIPPDOE88004.

Holt RM, Powers DW. 2010. Evaluation of halite dissolution at a radioactive waste disposal site, Andrews County, TX. Geological Society of America Bulletin 122: 1989-2004.

Lambert SJ. 1978. WIPP programs to investigate the nature and effects of salt dissolution and overburden subsidence in the vicinity of the WIPP site. In: Sandia National Laboratories and US Geological Survey. 1979. Basic data report for drillhole WIPP 25 (Waste Isolation Pilot Plant - WIPP). Albuquerque (NM): Sandia National Laboratories SAND79-0279. p. A2-A10.

Lambert SJ. 1983. Dissolution of evaporites in and around the Delaware Basin, southeastern New Mexico and west Texas. Albuquerque (NM): Sandia National Laboratories SAND82-0461.

Lee WT. 1925. Erosion by solution and fill. US Geological Survey Bulletin 760-C. p. 107-121.

Mercer JW. 1983. Geohydrology of the proposed Waste Isolation Pilot Plant site, Los Medaños area, southeastern New Mexico. US Geological Survey Water Resources Investigations Report 83-4016. $121 \mathrm{p}$.

Powers DW. 2014. Supplemental analysis report task 1B of AP-114, identify possible area of recharge to the Culebra west and south of WIPP. Report to Sandia National Laboratories, Carlsbad, NM.

Powers DW, Holt RM. 2000. The salt that wasn't there: mudflat facies equivalents to halite of the Permian Rustler Formation, southeastern New Mexico. Journal of Sedimentary Research 70 (1): 29-36.

Powers DW, Owsley D. 2003. A field survey of evaporite karst along NM 128 realignment routes. In: Johnson KS, Neal JT, editors. Evaporite karst and engineering/environmental problems in the United States. Oklahoma Geological Survey Circular 109. p. 233-240.

Powers DW, Beauheim RL, Holt RM, Hughes DL. 2006. Evaporite karst features and processes at Nash Draw, Eddy County, New Mexico. In: Land L, Lueth VW, Raatz W, Boston P, Love DL, editors. Caves and karst of southeastern New Mexico. New Mexico Geological Society Fiftyseventh Annual Field Conference Guidebook. p. 253-266.

Powers DW, Holt RM, Beauheim RL, McKenna SA. 2003. Geological factors related to the transmissivity of the Culebra Dolomite Member, Permian Rustler Formation, Delaware Basin, Southeastern New Mexico. In: Johnson KS, Neal JT, editors. Evaporite karst and engineering/ environmental problems in the United States. Oklahoma Geological Survey Circular 109. p. 211-218.

Robinson TW, Lang WB. 1938. Geology and groundwater conditions of the Pecos River valley in the vicinity of Laguna Grande de la Sal, New Mexico. New Mexico State Engineer 12th and 13th Biennial Reports. p. 79-100.

Rucker ML, Panda BB, Meyers RA, Lommler JC. 2013. Using InSAR to detect subsidence at brine wells, sinkhole sites, and mines. Carbonates \& Evaporites 28: 141-147.

US Department of Agriculture. 1986. Urban hydrology for small watersheds. Technical Release 55, US Department of Agriculture Natural Resources Conservation Service, Conservation Engineering Division (Appendix A updated January 1999).

Vine JD. 1963. Surface geology of the Nash Draw quadrangle, Eddy County, New Mexico. US Geological Survey Bulletin 1141-B. 46 p. 
Zhang A, Lu J, Kim J-W. 2018. Detecting mininginduced ground deformation and associated

hazards using spaceborne InSAR techniques.

Geomatics, Natural Hazards and Risk 9: 211-223. 